\title{
Options for Modernization of Heat Supply to Consumers of Condensing Power Plant
}

\author{
D. Balzamov*, I. Akhmetova, E. Balzamova
}

Kazan State Power Engineering University, Kazan, Russia.

\begin{abstract}
High competition and strict requirements of the wholesale electricity and capacity market make optimization of heat supply schemes an urgent issue for generating companies. Replacement of lifeexpired generation equipment with new capacities based on advanced technologies is a priority goal for the energy industry development. This work focuses on condensing power plant (CPP), which is the only source in the city that supplies heat to all consumer categories. The plant carries out quantitative and qualitative heat supply regulation according to the temperature profile of $135 / 70^{\circ} \mathrm{C}$ with a cutoff of $110 / 70^{\circ} \mathrm{C}$. The study examines the possibility of CPP modernization based on three options: building a pressure-reducing cooling unit $140 / 12$, commissioning an auxiliary boiler house, and building a $110 \mathrm{MW}$ combined-cycle gas plant. This paper presents technical solutions for the considered options and preliminary technical and economic calculations of their efficiency.
\end{abstract}

Index Terms: - auxiliary boiler house; boiler unit; combined-cycle gas plant; pressure-reducing cooling unit; water heater.

\section{INTRODUCTION}

This paper considers optimization solutions of a scheme of heat supply to consumers from a condensing power plant (CPP), which is the only source in the city. For reliable and uninterrupted heat supply during the heating period, part of the CPP power units operate at minimum loads of $110 \mathrm{MW}$, which leads to losses from electricity sales in the wholesale electricity and capacity market (WECM), since the cost of electricity generated at some points of time (night, weekends, holidays) exceeds market

\footnotetext{
* Corresponding author.

E-mail: dbalzamov@mail.ru
}

http://dx.doi.org/10.38028/esr.2021.02.0004

Received June 09, 2021. Revised June 25, 2021.

Accepted July 08, 2021. Available online July 23, 2021.

This is an open access article under a Creative Commons Attribution-NonCommercial 4.0 International License.

(C) 2021 ESI SB RAS and authors. All rights reserved. electricity prices. According to the data provided by the Production and Technical Department of the CPP, its loss in the year under consideration was RUR 50 million.

Thus, this study aims to:

1. Develop technical solutions to optimize the scheme of heat supply to urban consumers.

2. Evaluate the effectiveness of the solutions developed. The accomplishment of the set goals involved the analysis of:

1. The plant operating conditions.

2. The heat network operation.

3. The technical condition of the CPP equipment.

4. Heat and electricity generation, specific fuel consumption rates, and the development of the heat balance for the CPP.

\section{MATERIALS AND METHODS}

The following options are considered to optimize heat supply to consumers:

1. Construction of a pressure-reducing cooling unit (RCU) $140 / 12$ with a steam capacity of $50 \mathrm{t} / \mathrm{h}$, and reconstruction of RCU 12/6.

2. Commissioning of an auxiliary boiler house (ABH).

3. Construction of a combined-cycle gas plant (CCGP) with a capacity of $110 \mathrm{MW}$.

A. Construction of RCU 140/12 with a steam capacity of $50 \mathrm{t} / \mathrm{h}$ and reconstruction of $R C U 12 / 6$

To optimize heat supply with no additional units employed, one can construct RCU 140/12 with a steam capacity of $50 \mathrm{t} / \mathrm{h}$ (Fig. 1), which entails a reduced steam flow in the steam header of $12 \mathrm{~atm}$, then to the network water heater PSV-500-I (33.64 t/h of steam from RCU $140 / 12$ and $24.49 \mathrm{t} / \mathrm{h}$ of steam from two turbines using RCU 25/12) located in the turbine hall of stage 1 of the main building and through RCU 12/6 and a steam header of $7 \mathrm{~atm}$ to PSV-500-II (16.36 t/h from RCU 140/12 via RCU $12 / 6$ and $16.1 \mathrm{t} / \mathrm{h}$ from two turbine extractions via $\mathrm{RCU}$ $25 / 6$ ) located in the turbine compartment. With a nominal steam capacity of $640 \mathrm{t} / \mathrm{h}$ and nominal steam consumption of $575.5 \mathrm{t} / \mathrm{h}$ per turbine, the backup steam capacity of power boilers of each power unit is $64.5 \mathrm{t} / \mathrm{h}[1,2]$.

At the same time, the steam consumption through the $12 \mathrm{~atm}$ header will be: 


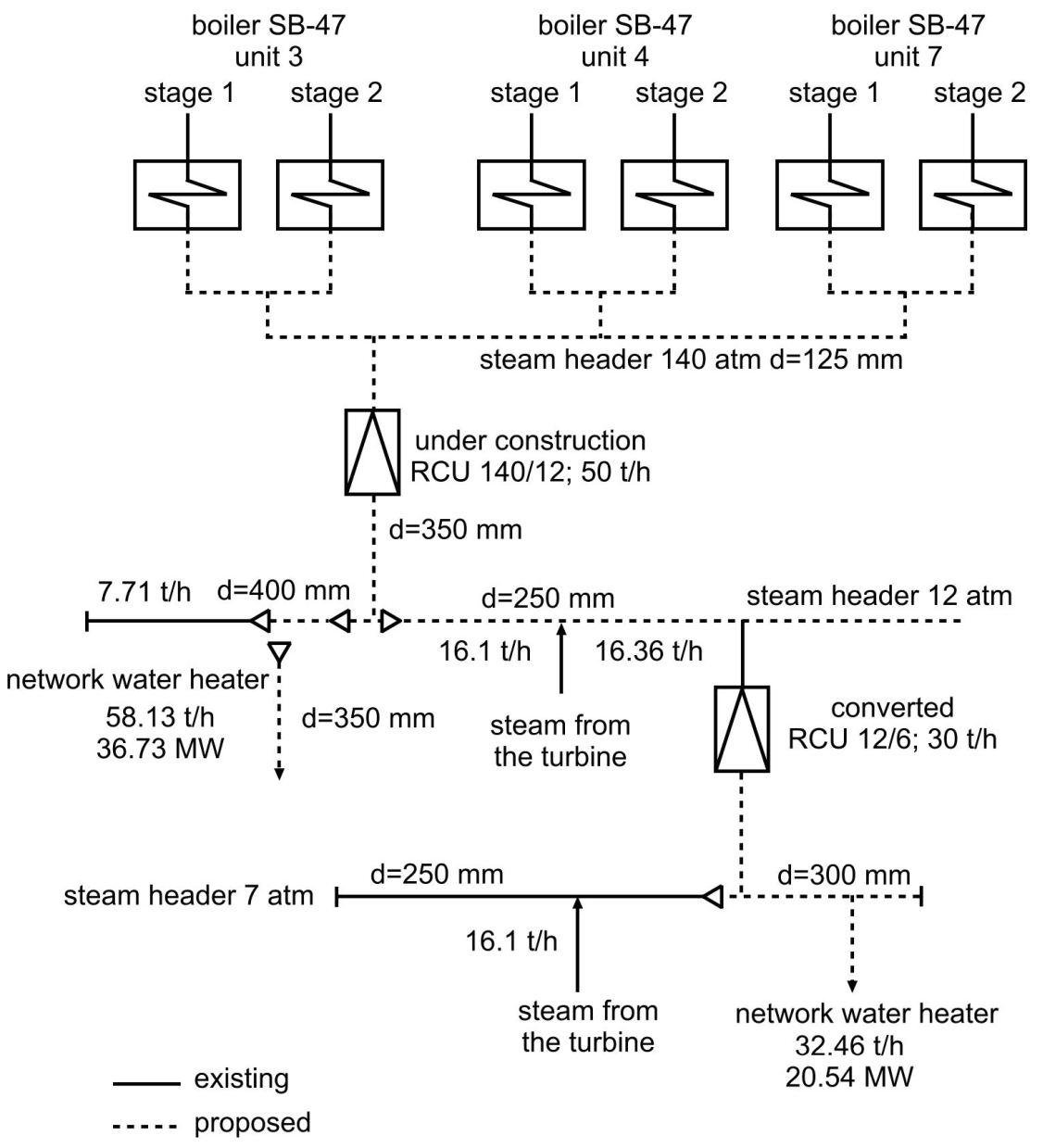

Fig. 1. Schematic diagram of $R C U$ 140/12 connection.

TABLE 1. Distribution of heat output under current conditions.

\begin{tabular}{lcccc}
\hline \multicolumn{1}{c}{ Source } & & \multicolumn{2}{c}{ Current conditions of heat output } & \\
& $\begin{array}{c}\text { Stage 1 } \\
\text { Quantity of power units }\end{array}$ & $Q, \mathrm{MW}(G, \mathrm{t} / \mathrm{h})$ & Quantity of power units & $Q, \mathrm{MW}(G, \mathrm{t} / \mathrm{h})$ \\
\hline From RCU 140/12 & & - & & - \\
From extraction 2 of turbines & 3 & - & 1 & - \\
$\begin{array}{l}\text { From extractions } 4 \text { and 5 of } \\
\text { turbines }\end{array}$ & & $31.65(63.24)$ & $16.08(25.94)$ \\
\hline \hline
\end{tabular}

TABLE 2. Distribution of heat output with RCU 140/12 in operation.

\begin{tabular}{|c|c|c|c|c|}
\hline \multirow{3}{*}{ Source } & \multicolumn{4}{|c|}{ Proposed heat supply scheme } \\
\hline & \multicolumn{2}{|l|}{ Stage 1} & \multicolumn{2}{|c|}{ Stage 2} \\
\hline & Quantity of power units & $Q, \operatorname{MW}(G, \mathrm{t} / \mathrm{h})$ & Quantity of power units & $Q, \operatorname{MW}(G, \mathrm{t} / \mathrm{h})$ \\
\hline From RCU 140/12 & & $21.26(33.64)$ & & $10.35(16.36)$ \\
\hline From extraction 2 of turbines & 1 & $10.29(16.1)$ & 1 & $10.29(16.1)$ \\
\hline $\begin{array}{l}\text { From extractions } 4 \text { and } 5 \text { of } \\
\text { turbines }\end{array}$ & & $20.53(27.7)$ & & $20.53(27.7)$ \\
\hline
\end{tabular}


TABLE 3. Distribution of heat output under current conditions.

\begin{tabular}{|c|c|c|c|c|}
\hline \multirow{3}{*}{ Source } & \multicolumn{4}{|c|}{ Current conditions of heat output } \\
\hline & \multicolumn{2}{|l|}{ Stage 1} & \multicolumn{2}{|c|}{ Stage 2} \\
\hline & Quantity of power units & $Q, \operatorname{MW}(G, \mathrm{t} / \mathrm{h})$ & Quantity of power units & $Q, \operatorname{MW}(G, \mathrm{t} / \mathrm{h})$ \\
\hline From RCU 140/12 & & - & & - \\
\hline $\begin{array}{l}\text { From extraction } 2 \text { of } \\
\text { turbines }\end{array}$ & 2 & $\begin{array}{l}3.04 \\
(4.8)\end{array}$ & 1 & $7.19(11.35)$ \\
\hline $\begin{array}{l}\text { From extractions } 4 \text { and } 5 \text { of } \\
\text { turbines }\end{array}$ & & $45.59(63.24)$ & & $22.80(31.62)$ \\
\hline
\end{tabular}

TABLE 4. Distribution of heat output with RCU 140/12 in operation.

\begin{tabular}{|c|c|c|c|c|}
\hline \multirow{3}{*}{ Source } & \multicolumn{4}{|c|}{ Proposed heat output scheme } \\
\hline & \multicolumn{2}{|c|}{ Stage 1} & \multicolumn{2}{|l|}{ Stage 2} \\
\hline & Quantity of power units & $\underset{\operatorname{MW}}{Q,}(G, \mathrm{t} / \mathrm{h})$ & Quantity of power units & $\begin{array}{c}Q, \\
\mathrm{MW} \\
(G, \mathrm{t} / \mathrm{h})\end{array}$ \\
\hline From RCU 140/12 & & $21.26(33.64)$ & & $10.35(16.36)$ \\
\hline $\begin{array}{l}\text { From extraction } 2 \text { of } \\
\text { turbines }\end{array}$ & 1 & $10.79(16.1)$ & 1 & $10.29(16.1)$ \\
\hline $\begin{array}{l}\text { From extractions } 4 \text { and } 5 \text { of } \\
\text { turbines }\end{array}$ & \multicolumn{3}{|c|}{$20.53(27.7)$} & $20.53(27.7)$ \\
\hline \multirow{3}{*}{ Source } & \multicolumn{4}{|c|}{\begin{tabular}{|c|} 
Current conditions of heat output \\
\end{tabular}} \\
\hline & Stage 1 & \multicolumn{2}{|c|}{ Stage 2} & \\
\hline & Quantity of power units & $\begin{array}{c}Q, \\
\operatorname{MW}(G, \mathrm{t} / \mathrm{h})\end{array}$ & Quantity of power units & $\begin{array}{c}Q, \\
\operatorname{MW}(G, \mathrm{t} / \mathrm{h})\end{array}$ \\
\hline From RCU 140/12 & & - & & - \\
\hline $\begin{array}{l}\text { From extraction } 2 \text { of } \\
\text { turbines }\end{array}$ & 5 & 7.76 & 3 & 4.95 \\
\hline $\begin{array}{l}\text { From extractions } 4 \text { and } 5 \text { of } \\
\text { turbines }\end{array}$ & & $113.97(158.1)$ & & $68.38(94.86)$ \\
\hline
\end{tabular}

- 50 t/h with RCU 140/12;

- $32.2 \mathrm{t} / \mathrm{h}$ from the second extraction of turbine units (2 power units);

- $58.13 \mathrm{t} / \mathrm{h}$ at PSV-500 of the first stage;

- $7.71 \mathrm{t} / \mathrm{h}$ for fuel oil production;

- $16.36 \mathrm{t} / \mathrm{h}$ with RCU 12/6.

The steam consumption through the 7 atm steam header at the same time will be:

- $16.36 \mathrm{t} / \mathrm{h}$ with RCU 12/6;

- $\quad 16.1 \mathrm{t} / \mathrm{h}$ from the second extraction of turbine units;

- $32.46 \mathrm{t} / \mathrm{h}$ for the PSV-500 network water heater of the second stage.
Distribution of heat output (at an outdoor temperature of $-5.2^{\circ} \mathrm{C}$ ) under current conditions and the conditions with RCU 140/12 in operation is presented in Tables 1 and 2.

In Table $1-6, Q$ is heat output, MW; $G$ is steam consumption, $\mathrm{t} / \mathrm{h}$.

Tables 1 and 2 indicate that commissioning of RCU $140 / 12$ at an outdoor temperature of $-5.2^{\circ} \mathrm{C}$ will allow the decommissioning of two power units and reduce the load on the remaining power units to $110 \mathrm{MW}$.

Distribution of heat output (at an outdoor temperature of -22 to $-24^{\circ} \mathrm{C}$ ) under current conditions and the conditions with RCU 140/12 in operation is presented in Tables 3 and 4. 
TABLE 6. Heat output distribution with RCU 140/12 in operation.

\begin{tabular}{|c|c|c|c|c|}
\hline \multirow{3}{*}{ Source } & \multicolumn{4}{|c|}{ Proposed heat output scheme } \\
\hline & \multicolumn{2}{|c|}{ Stage 1} & \multicolumn{2}{|c|}{ Stage 2} \\
\hline & Quantity of power units & $Q, \operatorname{MW}(G, \mathrm{t} / \mathrm{h})$ & Quantity of power units & $Q, \operatorname{MW}(G, \mathrm{t} / \mathrm{h})$ \\
\hline From RCU 140/12 & & $21.26(33.64)$ & & $10.35(16.36)$ \\
\hline $\begin{array}{l}\text { From extraction } 2 \text { of } \\
\text { turbines }\end{array}$ & 4 & $15.48(24.49)$ & 3 & $10.79(16.1)$ \\
\hline $\begin{array}{l}\text { From extractions } 4 \text { and } 5 \text { of } \\
\text { turbines }\end{array}$ & & $91.18(126.48)$ & & $68.38(94.86)$ \\
\hline
\end{tabular}

Tables 3 and 4 indicate that the commissioning of RCU $140 / 12$ at an outdoor temperature of -22 to $-24^{\circ} \mathrm{C}$ will allow decommissioning of one power unit and reducing a load of remaining power units to $110 \mathrm{MW}$.

Heat output distribution (at an outdoor temperature of $-34^{\circ} \mathrm{C}$ ) under current conditions and the conditions with RCU 140/12 in operation is presented in Tables 5 and 6.

Tables 5 and 6 show that commissioning of RCU $140 / 12$ at an outdoor temperature of $-34^{\circ} \mathrm{C}$ will allow decommissioning of one power unit.

To increase the flexibility of the heating plant when commissioning the new RCU 140/12, it is necessary to provide a cross-connection between the live steam boilers so that when one of the power units is stopped, RCU 140/12 remains in operation [3, 4]. Estimation of the power unit operation duration and equipment layout characteristics should take into account that crossconnection for live steam should be arranged between power units 3,4 , and 7 , as the most loaded ones $[5,6]$. The hot steam header diameter will be $125 \mathrm{~mm}$ to ensure the required performance of RCU 140/12.

The existing thermal capacity of the network water heater PSV-500 of the first stage with the parameters of heating steam $P=8 \mathrm{~atm}$ and $t=250^{\circ} \mathrm{C}$ is $15.58 \mathrm{MW}$, which corresponds to the consumption of $24.69 \mathrm{t} / \mathrm{h}$ of heating steam by PSV-500 of the first stage and $7.71 \mathrm{t} / \mathrm{h}$ by the fuel oil industry.

To increase steam consumption by PSV-500 of the first stage to $58.13 \mathrm{t} / \mathrm{h}(36.73 \mathrm{MW})$, it is necessary to relay the existing steam pipeline of 12 atm with a diameter of $250 \mathrm{~mm}$ :

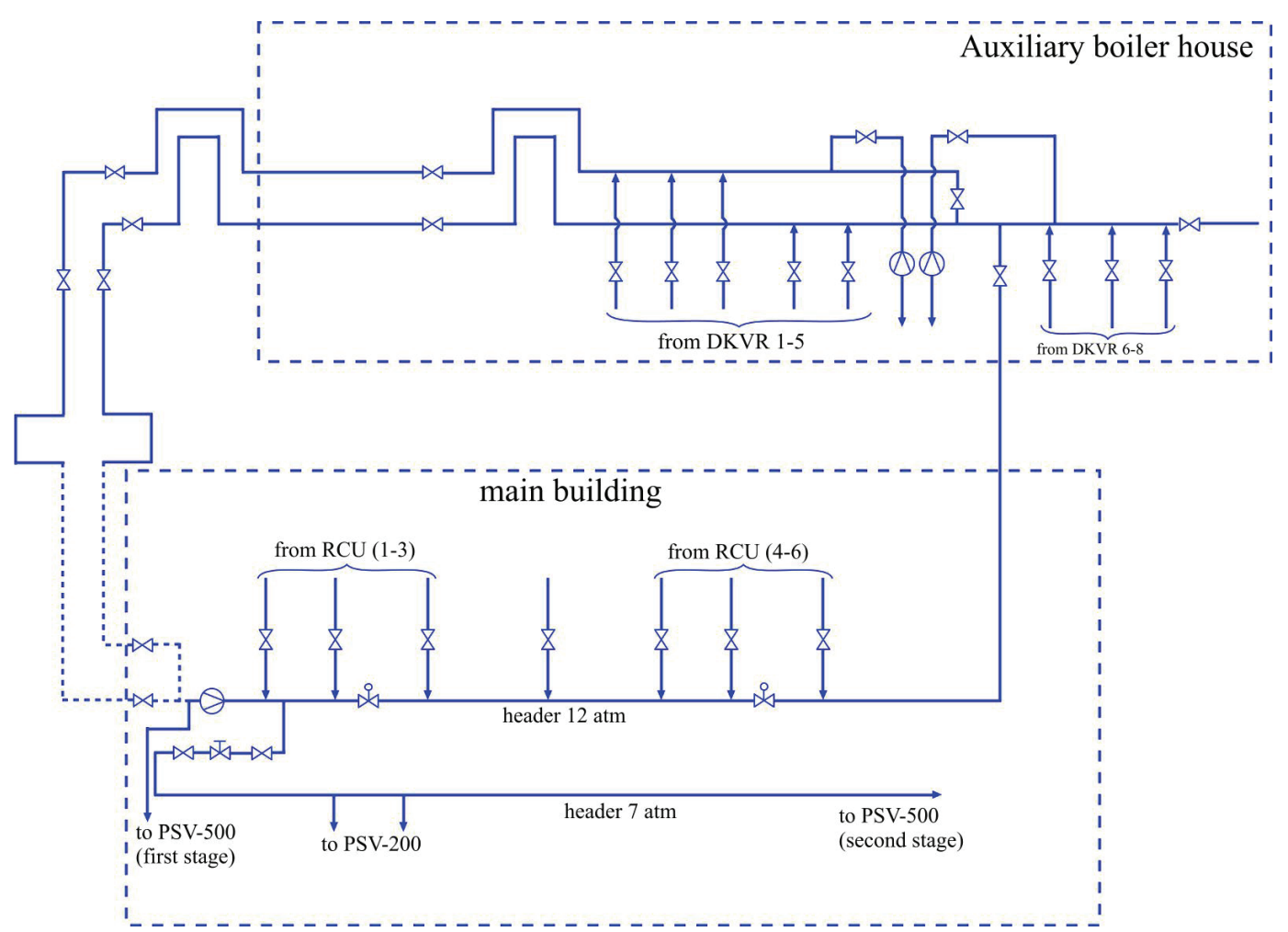

Fig. 2. The diagram of steam supply from ABH to the water heater PSV-500. 
- $\quad$ on the section from RCU $140 / 12$ to the tie-in to the 12 atm steam header of the first stage with a diameter of $350 \mathrm{~mm}$;

- on the section from the header with RCU 140/12 to the header to PSV-500 of the first stage with a diameter of $400 \mathrm{~mm}$;

- on the section from PSV-500 of the first stage to the tie-in to the $12 \mathrm{~atm}$ steam header with a diameter of $350 \mathrm{~mm}$.

\section{B. Commissioning of $A B H$}

The option of upgrading the existing heat supply scheme by commissioning the $\mathrm{ABH}$ [7-9] is suggested to optimize the heat supply from CPP without involving additional power units.

The diagram of the steam supply from $\mathrm{ABH}$ to the water heater PSV-500 of the first and second stages is presented in Fig. 2.

Commissioning of ABH implies the steam supply from the existing boiler house to the steam header of $12 \mathrm{~atm}[10$, $11]$.

There are seven steam boilers in the ABH. Technical parameters of the produced steam are $P_{\mathrm{o}}=23 \mathrm{~atm}, T_{\mathrm{o}}=$ $370^{\circ} \mathrm{C}$.

The boiler house is connected to the steam headers of 12 and 7 atm, which are located in the CPP main building.

According to the calculations, the actual steam production with parameters $P_{\mathrm{o}}=8 \mathrm{~atm}$ and $T_{\mathrm{o}}=210^{\circ} \mathrm{C}$ is $34.8 \mathrm{t} / \mathrm{h}$ by boilers DKVR-10-23 $(5.8 \mathrm{t} / \mathrm{h} \times 6 \mathrm{pcs} .=$ $34.8 \mathrm{t} / \mathrm{h}$ ) and $11.0 \mathrm{t} / \mathrm{h}$ by boiler DKVR-20-23. The total steam production by the boiler house is $45.8 \mathrm{t} / \mathrm{h}$ or 29.16 MW, which is slightly less than the total capacity of the boiler group, and the second extraction of one power unit at a load of $110 \mathrm{MW}(30.82 \mathrm{MW})$. The average weighted specific consumption of reference fuel (hereinafter fuel, in tonnes of oil equivalent, t.o.e.) for heat production for the boiler house will be $b_{\text {t.o.e. }-a b h}=136.8 \mathrm{~kg} / \mathrm{MW}$ [12-14].

Currently, boiler DKVR-10-23 is in operation. The service life of other boilers has expired.

Years of commissioning and service life extension of boilers are presented in Fig. 3.

As seen from Fig. 3, most boilers were put in service in 1967-1968, and service life for most of them has expired.

To increase the steam flow to the network water heater (PSV-500) of the first stage up to $70.49 \mathrm{t} / \mathrm{h}(44.54 \mathrm{MW})$, it is required to transfer the existing steam pipeline of $12 \mathrm{~atm}$ with a diameter of $250 \mathrm{~mm}$ from the condensate pump to PSV-500 of the first stage to the pipeline with a diameter of $400 \mathrm{~mm}$ [15].

Thus, the commissioning of $\mathrm{ABH}$ will allow removing no more than one power unit from the "forced" operation in the heating period $[16,17]$.

The annual hot water supply was $Q_{t a}=323618.7 \mathrm{MW}$ with an average annual specific fuel consumption for heat supply of $147.2 \mathrm{~kg} / \mathrm{MW}$.

Consumption of fuel for heat production at CPP [18] is as follows:

$$
\begin{aligned}
& G_{\text {t.o.e. }}=\left(Q_{\text {ta }} \cdot b_{\text {t.o.e.-h.y. }}\right) / 1000= \\
& =(323618.7 \cdot 147.2) / 1000 \approx 47636.7,
\end{aligned}
$$

where $b_{\text {t.o.e-h.y. }}$ is specific fuel consumption for heat production from thermal power plant.

The planned heat supply from $\mathrm{ABH}$ for three months (December, January, February) of the heating period is as follows:

$$
Q_{a b h}=29.16 \cdot 90 \cdot 24=62985.6,
$$

where:

- 29.16 is heat production by ABH, MW/hour;

- 90 is the duration of boiler operation, day;

- 24 is the number of hours per day, an hour.

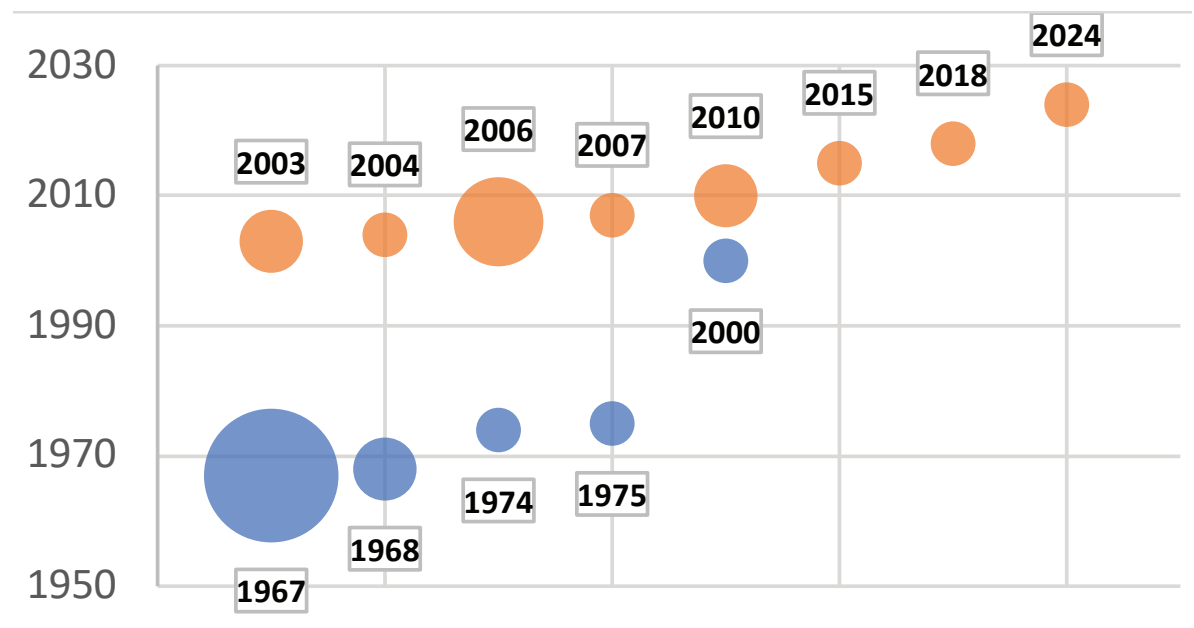

\section{Year of boiler commissioning \\ Year of boiler service life extension}

Fig. 3. Data on boiler commissioning and service life extension. 


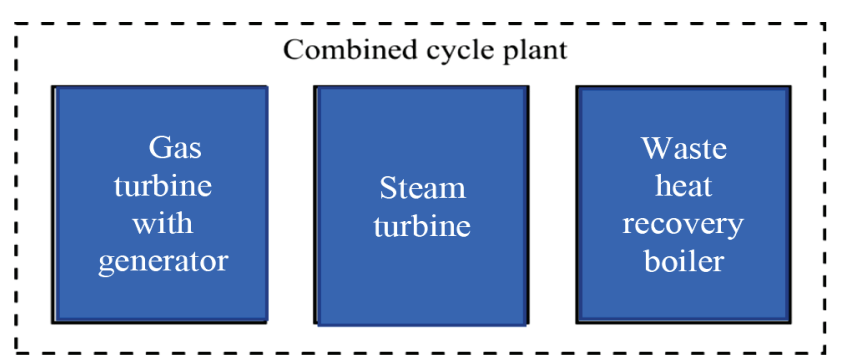

Fig. 4. The CCGP configuration.

TABLE 7. The preliminary cost of the project for 110 MW CCGP construction at CPP.

\begin{tabular}{|c|c|c|}
\hline No. & Type of work, equipment, and costs & $\begin{array}{c}\text { Price, RUR } \\
\text { million (without } \\
\text { VAT) }\end{array}$ \\
\hline 1 & $\begin{array}{l}\text { Equipment, including } \\
\text { gas turbine plants, } \\
\text { waste heat recovery boilers, } \\
\text { steam turbine plants, } \\
\text { electrical equipment, } \\
\text { auxiliary equipment. }\end{array}$ & 3000 \\
\hline 2 & Construction and installation & 900 \\
\hline 3 & Commissioning & 100 \\
\hline 4 & Design and survey & 200 \\
\hline 5 & Unforeseen expenses & 300 \\
\hline \multirow[t]{2}{*}{6} & $\begin{array}{l}\text { Dismantling of the existing power } \\
\text { unit }\end{array}$ & 500 \\
\hline & Total & 5000 \\
\hline
\end{tabular}

TABLE 8. Specific parameters of the 110 MW CCGP for heat and electricity supply.

\begin{tabular}{clc}
\hline \hline No. $\quad$ Type of work, equipment, and costs & $\begin{array}{c}\text { Price, RUR } \\
\text { million (without } \\
\text { VAT) }\end{array}$ \\
\hline & $\begin{array}{l}\text { Equipment, including } \\
\text { gas turbine plants, }\end{array}$ \\
& $\begin{array}{l}\text { waste heat recovery boilers, } \\
\text { steam turbine plants, }\end{array}$ & 3000 \\
& $\begin{array}{l}\text { electrical equipment, } \\
2\end{array}$ & auxiliary equipment. \\
3 & Construction and installation \\
4 & Commissioning & 900 \\
5 & Design and survey & 100 \\
6 & Unforeseen expenses & 200 \\
& Dismantling of the existing power & 300 \\
& unit & 500 \\
\hline \hline
\end{tabular}

Consumption of fuel for heat supply from $\mathrm{ABH}$ :

$$
G_{a b h}=\left(Q_{a b h} \cdot b_{\text {t.o.e. }-a b h}\right) / 1000=
$$$$
(62985.6 \cdot 136.8) / 1000 \approx 8616.4
$$

Heat supply from power units when involved in the $\mathrm{ABH}$ operation is:

$$
\begin{aligned}
& Q_{h . y .}=Q_{t a}-Q_{a b h}= \\
& =323618.7-62985.6=260633.1 .
\end{aligned}
$$

Fuel consumption for heat supply from power units when involved in the $\mathrm{ABH}$ operation is:

$$
\begin{aligned}
& G_{h . y .}=\left(Q_{\text {h.y. }} \cdot b_{\text {t.o.e. } h . y . y}\right) / 1000= \\
& =(260633.1 \cdot 147.2) / 1000 \approx 38365.2 .
\end{aligned}
$$

Fuel saving for hot water heat supply during the $\mathrm{ABH}$ operation (December, January, February) is as follows:

$$
\begin{aligned}
& E_{a b h}=G_{\text {t.o.e. }}-\left(G_{a b h}+G_{h . y}\right)= \\
& =47636.7-(8616.4+38365.2)=655.1,
\end{aligned}
$$

which corresponds to RUR 1.966 million.

C Construction of $110 \mathrm{MW}$ combined-cycle gas plant (CCGP)

Nowadays, one of the most common and successful solutions for replacing obsolete capacities is the construction of combined-cycle power units. In the Republic of Tatarstan, natural gas combined-cycle plants were put into operation at the Kazan CHPP-1 and CHPP2, the Yelabuga CHPP, and the Nizhnekamsk industrial zone, where they proved to be an effective solution for the combined electricity and heat generation.

The possibility of upgrading the CPP by constructing a 110 MW CCGP to deliver electricity to an outdoor $110 \mathrm{kV}$ switchgear and supply heat for heating needs is considered.

The CCGP configuration is shown in Fig. 4.

The heat output of a steam turbine with adjustable extractions used as part of a CCGP is 87.23 MW. An

\begin{tabular}{|c|c|c|}
\hline No. & Item & Estimated cost, RUR thousand \\
\hline 1 & Equipment & 19000 \\
\hline 2 & Revision of the existing project & 250 \\
\hline 3 & Replacement of RCU 12/6 & 2000 \\
\hline 4 & $\begin{array}{l}\text { Replacement of the } 12 \mathrm{~atm} \text { steam header with a diameter of } 400 \mathrm{~mm} \text { and replacement } \\
\text { of the } 12 \mathrm{~atm} \text { steam header with the PSV-500 }\end{array}$ & 3000 \\
\hline \multirow[t]{2}{*}{5} & Installation of gate valves & 1500 \\
\hline & Total & 25750 \\
\hline
\end{tabular}
increase in the efficiency of gas turbine exhaust gases can be achieved by installing gas network water heaters in the waste heat recovery boiler, which allow an additional production of about 5.82-6.98 MW. Thus, the total heat output of the combined-cycle plant will be 93.04-94.20

TABLE 9. Costs of the solution. 


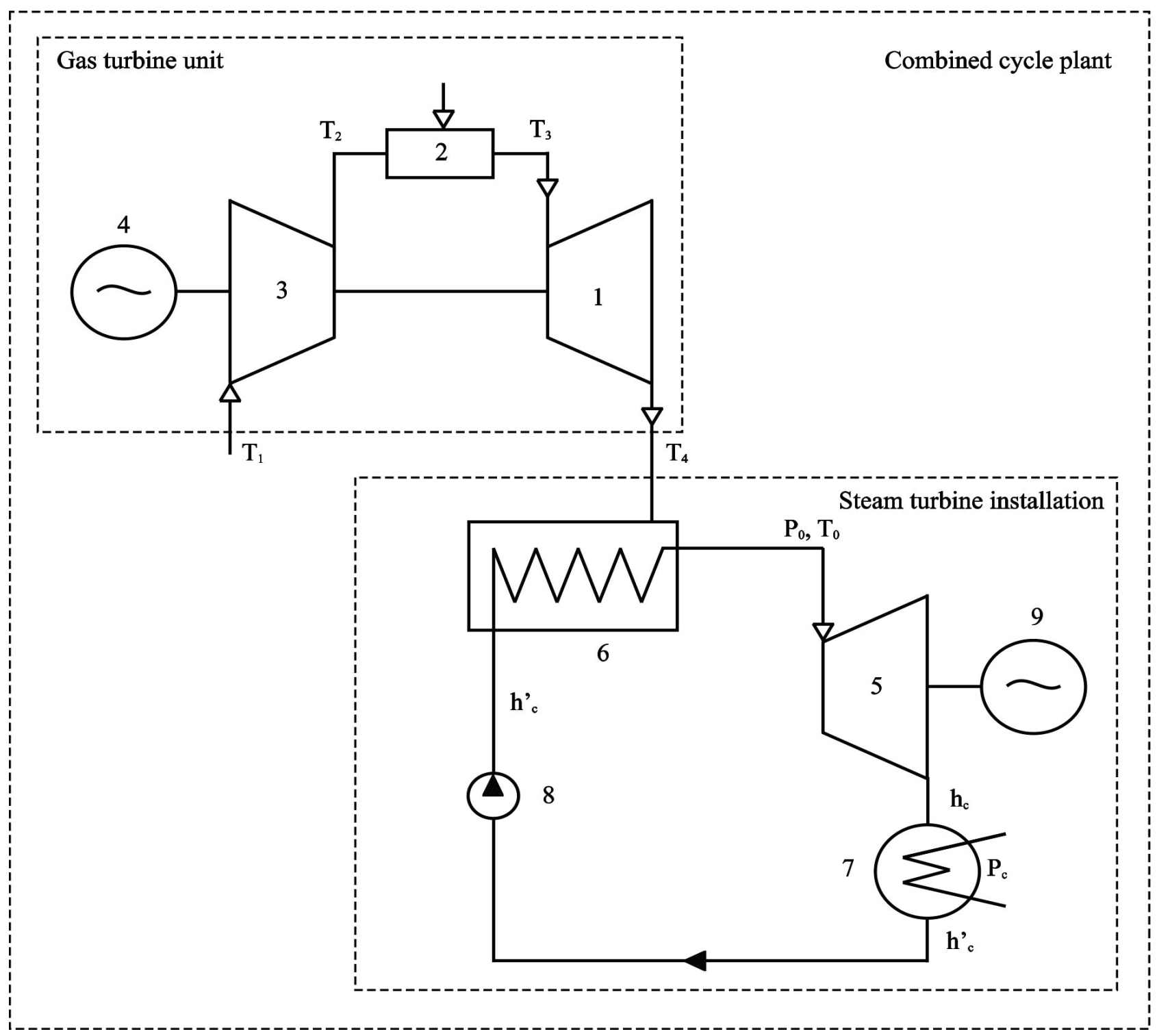

Fig. 5. The CCGP heat network diagram.

MW, which partially covers the heat demand of the residential area, the main building, and the industrial site of CPP (the heat load at a rated outdoor temperature of $-34^{\circ} \mathrm{C}$ is $\left.195.38 \mathrm{MW}\right)$.

The CPP heat flow diagram, including 100 MW CCGP, will provide heat supply to consumers as efficiently as possible [19].

An estimated cost of the project for $110 \mathrm{MW}$ CCGP construction at CPP is presented in Table 7 .

The cost of building the 110 MW combined-cycle plant, according to the calculations performed in the prefeasibility study for the construction of the unit, is RUR 4.5 billion. The cost of equipment indicated in Table 7 is based on technical and commercial quotes of manufacturers. The cost of items $2-6$ in Table 7 is determined factoring in the implemented projects for the construction of combinedcycle power units in the Republic of Tatarstan. Given the cost for dismantling of one CPP power unit, which is
RUR 0.5 billion, the total cost of this technical solution will be RUR 5.0 billion. According to expert estimates, the implementation period of this option will be three years. The heat network diagram of the CCGP is shown in Fig. 5. Table 8 indicates specific parameters of the $110 \mathrm{MW}$ CCGP.

The designations used in Fig. 5 are 1 - gas turbine; 2 - combustion chamber; 3 - compressor; 4 - compressor electric motor; 5 - steam turbine; 6 - heat recovery boiler; 7 - condenser; 8 - condensate pump; 9 - generator.

\section{RESULTS}

The results of the feasibility studies of the proposed technical solutions are presented below.

A. Construction of RCU 140/12 with a steam capacity of $50 \mathrm{t} / \mathrm{h}$ and reconstruction of $R C U 12 / 6$

The existing heating capacity of the network water heater PSV-500 of the second stage under the heating steam 
parameters $P=7$ atm and $t=250^{\circ} \mathrm{C}$ is $17.60 \mathrm{MW}$, which corresponds to the consumption of $27.8 \mathrm{t} / \mathrm{h}$ of heating steam of PSV-500 of the second stage (actual throughput of the pipeline is $27.8 \mathrm{t} / \mathrm{h}$ ).

To increase steam consumption at PSV-500 of the second stage to $32.46 \mathrm{t} / \mathrm{h}(20.64 \mathrm{MW})$, it is necessary to relay the existing steam pipeline with a pressure of 7 atm and diameter of $250 \mathrm{~mm}$ in the section from RCU 12/6 to PSV-500 of the second stage with a diameter of $300 \mathrm{~mm}$ to replace RCU $25 / 6$ due to its unsatisfactory technical condition.

The specific fuel consumption for heat production with the commissioning of RCU 140/12 will remain at the level of the existing actual values and amount to 146.17-147.9 kg.o.e./MW.

The costs of the option are summarized in Table 9.

The simple payback period is determined by the formula:

$$
\mathrm{C}=S_{\text {cost }} /\left(S_{\text {econ. }}-S_{\text {cost.year }}\right),
$$

where $S_{\text {cost }}$ is project costs, RUR thousand;

$S_{\text {cost.year }}$ is annual project costs, RUR thousand $\left(S_{\text {cost.year }}=0\right)$;

$S_{\text {econ }}$ is the total economic effect of the project for the heating period determined by the financial results of the source activity in the wholesale electricity and capacity market in the months with losses $\left(S_{\text {econ }}=\right.$ RUR 50000 thousand). Information provided by the station's technical department.

The simple payback period will be:

$$
C=25750 / 50000 \approx 0.5
$$

of the heating period.

At the same time, the specific capital investment per 1 Gcal is determined by the formula:

$$
\mathrm{K}=S_{\text {cost }} / W_{\text {power }}
$$

where $W_{\text {power }}$ is heat output of the commissioned equipment, MW (30.18 MW).

The specific capital investment (RUR million) per 1 MW will be:

$$
\mathrm{K}=25.750 / 30.18 \approx 0.853 \text {. }
$$

\section{B. Commissioning of $A B H$}

The annual cost of maintaining the $\mathrm{ABH}$ performance:

- Maintenance and repair of instrumentation, material, and equipment are RUR 1.3 million.

- Operating costs, maintenance of boilers and additional equipment are RUR 0.68 million.

The payback period is calculated by the formula:

$$
C=S_{\text {cost }} /\left(S_{\text {econ }}-S_{\text {an.cost }}\right),
$$

where:

$S_{\text {cost }}$ is the costs of the project, RUR 39250 thousand;

$S_{\text {an.cost }}$ is the annual costs of the project, RUR 1980 thousand;

$S_{\text {econ }}$ is the project economic effect during the heating period (49 $899+1966$, RUR thousand), where 49899 is the plant's loss according to the Finance Department; 1966 is fuel saving for the period of the $\mathrm{ABH}$ operation.

The payback period is:

$$
C=39250 /(49899+1966-1980) \approx 0.79
$$

of heating period.

The formula determines specific capital investment (RUR million) per $1 \mathrm{MW}$ :

$$
K=S_{\text {cost }} / W_{\text {power }}
$$

where $W_{\text {power }}$ is the heat capacity of the new equipment, Gcal/h (29.16 MW).

Specific capital investment (RUR million) per $1 \mathrm{Gcal}$ is:

$$
K=39.25 / 29.16 \approx 1.35 \text {. }
$$

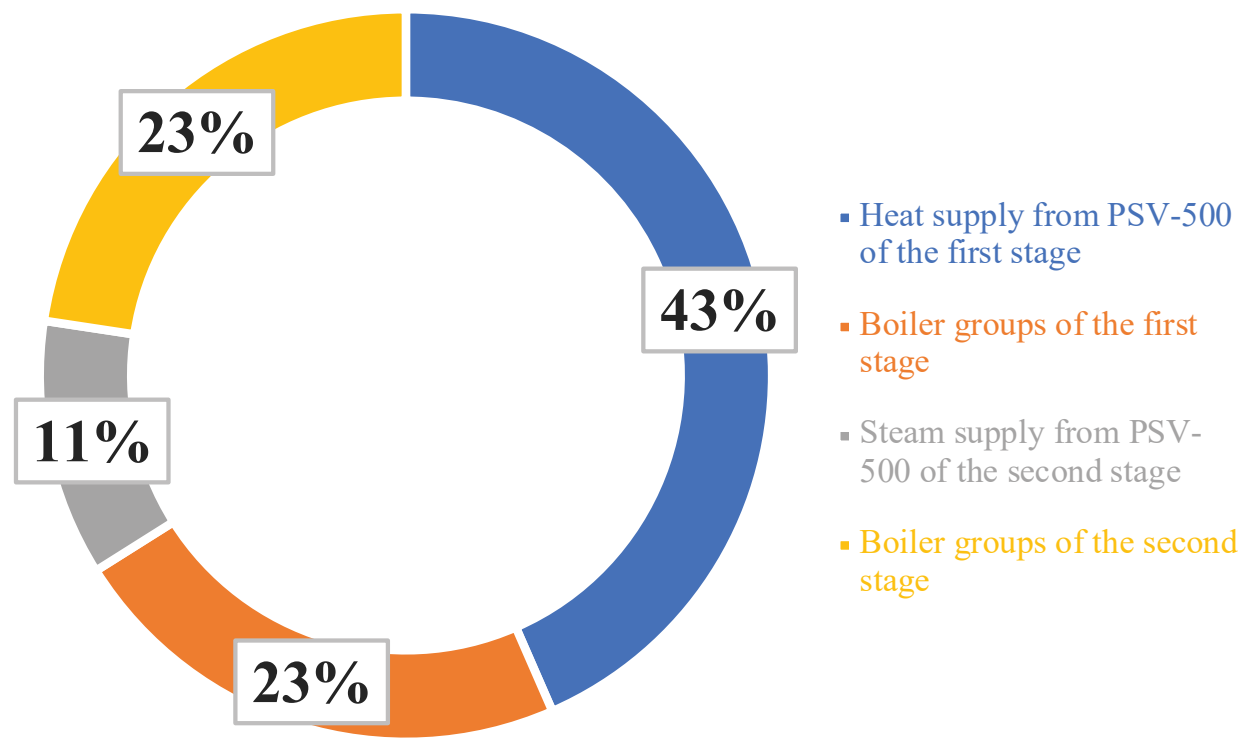

Fig. 6. Unit commitment required to meet heat load at an air temperature of $-24^{\circ} \mathrm{C}$. 
Figure 6 presents the unit commitment necessary to ensure the heating load of consumers. Thus, the most significant heat supply is from PSV-500 of the first stage.

\section{Construction of $110 \mathrm{MW} C \mathrm{CGP}$}

Annual fuel saving in hot water heat generation at 110 MW CCGP was calculated according to the following algorithm [20].

Fuel consumption for hot water heat supply under the existing scheme will be:

$$
\begin{aligned}
& G_{\text {t.o.e. }}=\left(Q_{t g} \cdot b_{\text {t.o.e.-h.y. }}\right) / 1000= \\
& =(278262 \cdot 147.2) / 1000 \approx 40960.2,
\end{aligned}
$$

where $Q_{t g}$ is heat output for hot water according to the Technical Department.

Fuel consumption for heat production with the 110 MW CCGP in operation will be:

$$
\begin{aligned}
& G_{c c p}=\left(Q_{t g} \cdot b_{h / p-c c p-110}\right) / 1000= \\
& =(278262 \cdot 126.91) / 1000 \approx 35314.23,
\end{aligned}
$$

where $b_{h / p-c c p-110}$ is specific fuel consumption for heat production at a combined cycle gas plant.

Annual fuel saving for heat supply from the CPP will be:

$$
\begin{aligned}
& E_{\text {year } h / p}=G_{\text {t.o.e. }}-G_{c c p}= \\
& =40960.2-35314.23=5645.97 .
\end{aligned}
$$

The saving was calculated for the following initial conditions:

- the number of utilization hours of 110 MW CCGP is 8300 h./y.;

- the combined cycle gas plant operates for a base-load power generation of $110 \mathrm{MW}$.

According to the reported data, the actual electricity output of CPP is 8662876 thousand $\mathrm{kWh}\left(E_{\text {aeo }}\right)$.

The average annual specific consumption of fuel for electricity generation is $349 \mathrm{~g} / \mathrm{kWh}$.

Fuel consumption for electricity generation at the whole plant is:

$$
G_{\text {t.o.e. }}=(8662876000 \cdot 349) / 10^{6} \approx 3023343.7 .
$$

Power generation at $110 \mathrm{MW}$ CCGP, MWh, is:

$$
E_{c c p}=(110000 \cdot 8300) / 10^{3}=913000 .
$$

Power output from 110 MW CCGP, MWh, is:

$$
E_{\text {ccp vac. }}=(110000 \cdot 8300) / 10^{3} \cdot 0.9404=858585.2 \text {. }
$$

According to the reported data, the auxiliary power consumption is $5.96 \%$.

Fuel consumption for electricity supply from $110 \mathrm{MW}$ CCGP is:

$$
G_{c c p}=(858585200 \cdot 252.4) / 10^{6} \approx 216706.9,
$$

where 252.4 is specific fuel consumption for electricity supply (Table 8 ).

Electricity supply by power units of the plant without electricity supply from 110 MW CCGP, MWh, is:

$$
\begin{aligned}
& E_{e b}=E_{a e o}-E_{c c p v a c .}= \\
& =8662876-858585.2=7804290.8 .
\end{aligned}
$$

Fuel consumption for electricity supply by power units of the plant, excluding 110 MW CCGP, is:

$$
\begin{aligned}
& G_{\text {t.o.e.ebb }}=\left(E_{e b} \cdot b_{e b}\right) / 10^{6}= \\
& =(7804290800 \cdot 348.8) / 10^{6} \approx 2722136.6,
\end{aligned}
$$

where $b_{e b}$ is average specific fuel consumption for electricity generation.

Annual fuel saving for CPP is:

$E_{\text {year e/p }}=G_{\text {t.o.e. }}-G_{c c p}-G_{\text {t.o.e.e.eb }}=$

$=3023343.7-216706.9-2722136.6=84500.2$.

The total annual fuel saving due to the commissioning of 110 MW CCGP will be:

$$
\begin{aligned}
& E_{\text {year }}=E_{\text {year } h / p}+E_{\text {year e/p }}= \\
& =5645.97+84500.2=90146.17 .
\end{aligned}
$$

The expected economic effect of the project (RUR million) will be:

$$
\begin{aligned}
& S_{\text {sav. }}=E_{\text {year }} \cdot Z_{f} / 10^{6}= \\
& =90146.17 \cdot 4700 / 10^{6} \approx 423.69,
\end{aligned}
$$

where $Z_{f}=4700 \mathrm{RUR} /$ t.o.e. is the fuel cost.

The formula for calculating the payback period is:

$$
\mathrm{PP}=S_{\text {cost }} / S_{\text {sav }} .
$$

The simple payback period will be:

$$
P P=5000 / 423.69 \approx 11.80 .
$$

In this case, the specific CapEx per 1 Gcal are determined by the formula:

$$
S C I=S_{\text {cost } .} / W_{\text {power }}
$$

where $W_{\text {power }}$ is the heat output of the newly introduced equipment, Gcal /h (94.2 MW).

The specific capital investment (RUR million) per 1 MW will be:

$$
S C I=5 \text { 000/94.2 } \approx 53.08 \text {. }
$$

\section{CONCLUSION}

The optimization option of the heat supply scheme based on the construction of RCU 140/12 with a steam capacity of $50 \mathrm{t} / \mathrm{h}$ will partially cover the district heating load of $29.08 \mathrm{MW}$ and $110.45 \mathrm{MW}$. The remaining power units can operate at a $110 \mathrm{MW}$ load.

The commissioning of $\mathrm{ABH}$ with lower parameters partially reduces the plant heating load of 29.16 MW, which provides a heat output of one CPP power unit under "forced" heat generation. The remaining power units can operate at a $110 \mathrm{MW}$ load.

The main criterion for the option of 110 MW CCGP is the replacement of obsolete generating equipment with new capacities.

At the same time, the option of building the $110 \mathrm{MW}$ CCGP with a heat output of 94.2 MW with a calculated 
heating load of 195.38 MW does not fully solve the problem of upgrading the heat supply scheme.

With the project period of about 4.5-5 years, there can be considerable losses due to power units operating under the conditions of "forced" heat generation. Nevertheless, it is worth noting that CCGPs are a promising option for the energy industry due to their high efficiency and acceptable payback periods within the framework of power supply contract programs designed to provide the investment in the construction of new generating capacities.

\section{ACKNOWLEDGMENTS}

The study was carried out within the framework of the scientific project of the Russian Science Foundation (RSF) No 18-79-10136.

\section{REFERENCES}

[1] Tongjun Zhang, "Methods of Improving the Efficiency of Thermal Power Plants," Journal of Physics: Conf. Ser., vol. 1449, 012001, 2020.

[2] O.S. Kharitonova, V.V. Bronskaya, T.V. Ignashina, A. Al-Muntaser, and L.E. Khairullina, "Modeling of absorption process using neural networks," IOP Conference Series: Earth and Environmental Science, vol. 315, 032025, 2019.

[3] Yu.N. Zatsarinnaya, N.A. Staroverova, M.M. Volkova, S.I. Galymullina, and R.K. Khakimzyanov, "Heat supply system computer laboratory stand development," IOP Conf. Ser.: Earth Environ. Sci., vol. 288, 012131, 2019.

[4] Soloveva O.V., Solovev S.A., Yafizov R.R. "Determination of the particle deposition efficiency value in a granular and open-cell foam filter," IOP Conf. Ser. Mater. Sci. and Eng., vol. 709(3), 033064, 2020.

[5] D.S. Balzamov, E.Yu. Balzamova, V.V. Bronskaya, T.V. Ignashina, and O.S. Kharitonova, "Analysis of the possibility of modernization of the state district power station by building the combined cycle plant," Journal of Physics: Conf. Ser., vol. 1515, 042100, 2020.

[6] G.A. Aminova, G.V. Manuiko, T.V. Ignashina, V.V. Bronskaya, N.E. Kharitonova, G.S. D’yakonov, and V.P. Arkhireev, "Optimal parameters of butadiene polymerization in the synthesis of rubber on a neodymium-containing catalytic system," Theoretical Foundations of Chemical Engineering, vol. 40, pp. 59-67, 2006.

[7] E.Yu. Balzamova, D.S. Balzamov, V.V. Bronskaya, and O.S. Kharitonova, "Modernization of the scheme for the delivery of thermal power from the state district power station," IOP Conf. Ser.: Mater. Sci. Eng., vol. 734, 012194, 2020.

[8] O.V. Soloveva, "Comparison of granular and opencell foam filter models by numerical simulation," IOP Conf. Ser.: Earth and Env. Sci., vol. 421(6), 062038, 2020.

[9] A. Zhigurs, Y. Golunovs, D. Tourlayss, and S. Pliskachev, "Flue gas heat recovery in Riga heat sources," Heat Supply News, vol. 5, pp. 19-24, 2010.
[10] J.N. Zatsarinnaya, A.G. Logacheva and A.A. Solovyova, "Analysis of thermodynamic efficiency of the fuel preparation systems with an intermediate hopper at thermal power plants," IOP Conf. Ser.: Earth Environ. Sci., vol. 288, 012130, 2019.

[11] I.A. Konakhina, A.M. Konakhin, and O.P. Shinkevich, "Thermodynamic analysis of the system for collection and re-use of condensate," Bulletin of Ivanovo State Energy University, vol. 2, pp. 11-14, 2011.

[12] S.A. Solovev, O.V. Soloveva, B.Sh. Gilmurahmanov and A. Lamberov, "Numeral simulation of a flow mixer for a radial-type chemical reactor," IOP Conf. Ser.: Earth Environ. Sci., vol. 421, 072017, 2020.

[13] US 2010/0077722 A1 Peak load management by combined cycle power augmentation using peaking cycle exhaust heat recovery 30.09.2008, General Electric Company, Ajit Singh Sengar, Saravanan Venkataraman Nattanmai, Shivaprasad Lokanath.

[14] Michael McManus David Boyce Raymond Baumgartner, Integrated Technologies that Enhance Power Plant Operating Flexibility POWER-GEN International 2007 New Orleans, LA Dec 11-13, 2007, (C) Siemens AG 2007

[15] H. Emberger, E. Schmid and E. Gobrecht, Fast Cycling Capability for New Plants and Upgrade Opportunities Siemens Power Generation (PG), Germany C Siemens AG 2005.

[16] V.I. Sharapov and M.E. Orlov, Technologies for ensuring peak load of heat supply systems. Moscow: Publishing house "News of Heat Supply," 2006, 208 $\mathrm{p}$

[17] O. Soloveva, S. Solovev, R. Khusainov, R. Yafizov, "Mathematical modeling of heat transfer in open-cell foam of different porosities," Advances in Intelligent Systems and Computing, vol. 1259 AISC, pp. 371382, 2021.

[18] A.I. Andryushchenko "Modern problems of heat supply to cities and rational ways to solve them," Vestnik SSTU, No 3, pp. 110-115, 2005.

[19] V.M. Kravchenko, "Current state of the heat supply industry," Report of the Ministry of Energy of Russia, March 2016, Moscow.

[20] D.S. Balzamov, I.G. Akhmetova, E.Yu. Balzamova, G.I. Oykina, and V.V. Bronskaya, "Options for organizing own sources of energy supply at the facilities of generating companies based on steam screw machines," Journal of Physics: Conference Series, vol. 1399(5), 055018, 2019.

[21] E.K. Arakelyan, V.A. Starshinov, Improving the efficiency and maneuverability of thermal power plants equipment. Moscow: Publishing house of MEI, 1993, $326 \mathrm{p}$. 


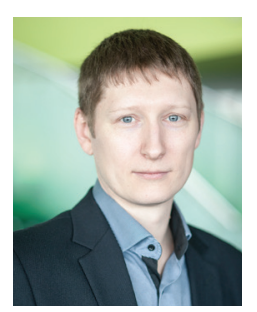

Denis Balzamov, Ph.D. in Industrial Heat Power Engineering, Associate Professor of the Department "Power Supply to Enterprises and Energy Saving Technologies" of Kazan State Power Engineering University, Kazan, Russia. Research interests are energy saving at the enterprises of the fuel and energy complex, energy technology combination.

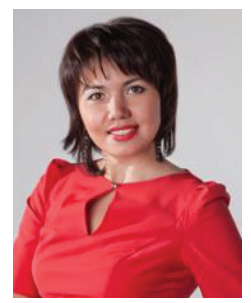

Irina Akhmetova, D.Sc. in Industrial Heat Power Engineering, Vice-Rector for Research, Kazan State Power Engineering University, Kazan, Russia. Research interests are optimization of heat supply systems to increase the energy efficiency of heat supply sources.

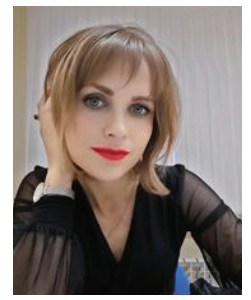

Elena Balzamova, Master of Engineering and Technology in Heat Power Engineering, assistant of the Department of Economics and Organization of Production, Kazan State Power Engineering University, Kazan, Russia. Research interests are feasibility studies of investment projects aimed at increasing energy efficiency. 